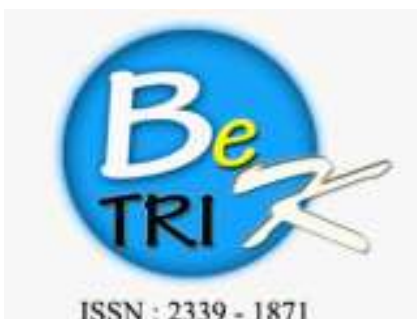

JURNAL ILMIAH BETRIK

Editor Office : LPPM Sekolah Tinggi Teknologi Pagar Alam, Jln. Masik Siagim No. 75 Simpang Mbacang, Pagar Alam, SUM-SEL, Indonesia Phone : +62 852-7901-1390.

Email : betrik@lppmsttpagaralam.ac.id / admin.jurnal@1ppmsttpagaralam.ac.id Website : https://ejournal.lppmsttpagaralam.ac.id/index.php/betrik/index

\title{
APLIKASI PENGELOLAAN DATA PENDUDUK DENGAN PEMROGRAMAN PHP ( STUDI KASUS : KECAMATAN SUKA MERINDU)
}

\author{
Desi Puspita1 $^{1}$, Buhori Muslim², Siti Aminah ${ }^{3}$ \\ Program Studi Teknik Informatika Sekolah Tinggi Teknologi Pagar Alam ${ }^{123}$ \\ JalanMasik Siagim No.75 Simpang Mbacang Kec.Dempo Tengah Kota Pagar Alam
}

Sur-el : desiofira1@gmail.com ${ }^{1}$, buhoristtp@gmail.com ${ }^{2}$, gosupeta@gmail.com ${ }^{3}$

\begin{abstract}
Abstrak: Pengelolaan data penduduk di Kantor Camat Sukamerindu masih dilakukan secara manual yaitu dengan pencatatan data penduduk berdasarkan beberapa pengelompokkan kategori, yaitu pengelompokkan berdasarkan data lahir, data KTP (Kartu Tanda Penduduk), data kartu keluarga (KK), data pindah dan data meninggal. Semua data diperoleh dengan pendataan sensus oleh petugas kecamatan yang kemudian dibukukan pada buku pendataan Penduduk, arsip data berupa dokumen tersebut yang kemudian disalin kembali menggunakan aplikasi Microsoft Office Word dan Microsoft Office Excel. Tujuan penelitian adalah untuk menghasilkan aplikasi penegelolaan data penduudka dengan pemrograman PHP. Metode Pengembangan menggunakan Web Engineering antara lain : Communication, Planning, Modeling, Contruction dan Deployment. Hasil penelitian berupa Aplikasi Pengelolaan Data Penduduk untuk mempermudah dan mempercepat pengolahan data penduduk di Kecamatan Sukamerindu.
\end{abstract}

Kunci Utama: Aplikasi, Pengelolaan, PHP, Web Engineering.

\begin{abstract}
Managing population data at the Sukamerindu Sub-district Office is still done manually, namely by recording population data based on several categories of categories, namely grouping based on birth data, ID cards (ID cards), family card data (KK), data moved and data dies. All data was obtained by census data collection by sub-district officials who were then recorded in the Population data collection book, data files in the form of documents were then copied back using Microsoft Office Word and Microsoft Office Excel applications. The purpose of the study was to produce a data management application with PHP programming. Development methods using Web Engineering include: Communication, Planning, Modeling, Contruction and Deployment. The results of the study are in the form of Application for Population Data Management to simplify and speed up the processing of population data in Sukamerindu.
\end{abstract}

Keywords : Applications, Management, PHP, Web Engineering

\section{PENDAHULUAN}

Perkembangan teknologi yang sangat cepat mendorong kebutuhan akan informasi yang cepat dan akurat mengenai data penduduk di Indonesia. Banyaknya data yang dikelola dan perlunya penyampaian Informasi yang cepat dalam kegiatan pelayanan administrasi kependudukan di Indonesia, menjadikan Teknologi Informasi sebagai media yang dianggap mampu membantu dalam 
pengelolaan data dan penyajian Informasi yang cepat, mudah, dan akurat. Instansi pemerintah perlu mengikuti perkembangan teknologi dan terus meningkatkan kemampuannya dalam mengelola data-data yang lebih maksimal (Merzalino, 2013).

Dengan adanya perkembangan teknologi informasi yang sangat pesat khususnya di bidang komputerisasi, mendorong banyak instansi dan organisasi negara maupun swasta untuk memanfaatkan teknologi informasi ini agar mampu bersaing dengan lajunya perkembangan dunia teknologi modern ini. Begitu pula dengan pemanfaatan teknologi informasi di bidang Pemerintahan di Indonesia. Sejalan dengan arah perkembangan Teknologi Informasi maka pengelolaan data penduduk sebagai subsistem dari administrasi kependudukan yang perlu ditata dengan sebaikbaiknya agar dapat memberikan manfaat dalam perbaikan pemerintahan dan pembangunan. (Muttaqien, 2014).

Pengelolaan data penduduk di Kantor Camat Sukamerindu masih dilakukan secara manual yaitu dengan pencatatan data penduduk berdasarkan beberapa pengelompokkan kategori, yaitu pengelompokkan berdasarkan data lahir, data KTP (Kartu Tanda Penduduk), data kartu keluarga (KK), data pindah dan data meninggal. semua data diperoleh dengan pendataan sensus oleh petugas kecamatan yang kemudian dibukukan pada buku pendataan Penduduk, arsip data berupa dokumen tersebut yang kemudian disalin kembali menggunakan aplikasi Microsoft Office Word dan Microsoft Office Excel.
Berdasarkan latar belakang di atas, maka peneliti membuat sebuah Aplikasi Pendataan Penduduk menggunakan pemrograman PHP untuk mempermudah didalam pendataan penduduk.

Rumusan masalah yang diperoleh dari latar belakang di atas adalah "Bagaimana membuat Aplikasi Pengelolaan Data Penduduk Pada Kantor Camat Sukamerindu menggunakan PHP dan MySQL" yang dapat menampilkan informasi tentang data penduduk di Kecamatan Sukamerindu Kabupaten Lahat.

Untuk menghindari hal-hal yang menyimpang dari maksud dan tujuan sebenarnya, penulis membatasi permasalahan hanya pada pengolahan data penduduk di Kecamatan Suka merindu yang terdiri dari : Input data, yang meliputi, Data Lahir, KTP (Kartu Tanda Penduduk), KK (Kartu Keluarga), Pindah dan Meninggal. Output Data, yang meliputi, Data Lahir, KTP (Kartu Tanda Penduduk), KK (Kartu Keluarga), Pindah dan Meninggal.

Tujuan utama yang ingin dicapai dalam penelitian ini, adalah untuk menghasilakan Aplikasi Pengelolaan Data Penduduk yang bermanfaat untuk pengaksesan informasi yang cepat dan akurat, dan memperbaharui sistem pendataan penduduk di Kecamatan Sukamerindu Kabupaten Lahat.

\section{METODE PENELITIAN}

\subsection{Metode Pengumpulan Data}

Metode pengumpulan data yang digunakan dalam penyusunan skripsi ini terdiri dari beberapa macam metode, yaitu : 
a. Wawancara

Data yang dikumpulkan yaitu diperoleh dengan cara penulis melalukan tanya jawab langsung kepada Camat atau kepala Staf kantor camat sukamerindu yang berkaitan dengan masalah yang akan dipecahkan sehingga penulis dapat memperoleh data dan keterangan yang benar-benar akurat.

\section{b. Dokumentasi}

Pencarian data ini dilakukan dengan mengintip dan memperhatikan data yang diperoleh baik arsip dan lain-lainnya arsip yang ada di Kantor Camat Sukamerindu.

c. Studi pustaka

Studi pustaka dilakukan dengan cara mempelajari teori-teori literatur dari buku-buku yang berhubungan dengan objek peneitian sebagai bahan atau dasar pemecahan masalah.

\subsection{Metode Pengembangan Sistem}

Dalam pengembangan sistem ini metode pengembangan menggunakan Metode Web Engineering (Rekayasa web), karena metode ini memberikan ide bagi pengembang maupun user tentang cara sistem akan berfungsi dan akan dikembangkan. (Rohmat Taufiq, Sistem Informasi Manajemen, 2013)

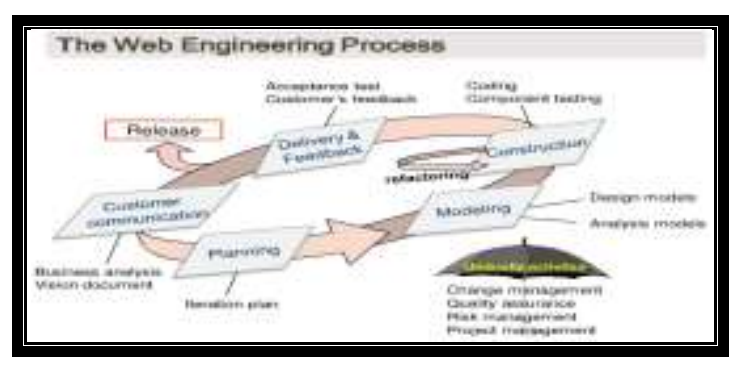

Gambar 1. Metode Web Engineering

Tahapan-tahapan tersebut, yaitu :

1. Komunikasi (Communication)
Sebelum pekerjaan teknis apa pun dimulai, sangatlah penting untuk berkomunikasi dan berkolaborasi dengan pelanggan (dan para pemangku kepentingan yang lain). Maksudnya adalah untuk memahami tujuan -tujuan atas proyek perangkat lunak yang sedang dikembangkan dan mengumpulkan kebutuhankebutuhan yang akan membantu mengartikan fitur-fitur perangkat lunak beserta fungsifungsinya.

\section{Perencanaan (Planning)}

Alur yang rumit dapat disederhanakan jika terdapat suatu peta. Suatu proyek perangkat lunak pada dasarnya merupakan suatu alur yang rumit, dan kegiatan perencanaan perangkat lunak tersebut menciptakan suatu "peta" yang membantu membimbing tim perangkat lunak ketika mereka melakukan suatu perjalanan. Peta perangkat lunak tersebut yang disebut sebagai rencana proyek perangkat lunak. Mengartikan kerja rekayasa perangkat lunak dengan menggambarkan tugas-tugas teknis yang harus dilakukan, resiko-resiko yang mungkin muncul, sumber daya yang akan dibutuhkan, produk-produk kerja yang harus dihasilkan, dan jadwal-jadwal kerja.

\section{Pemodelan (Modeling)}

Tujuan dari aktivitas ini adalah untuk menjelaskan hal apa saja yang memang diperlukan/dibutuhkan pada aplikasi yang akan dibangun dan solusi yang ditawarkan yang dapat diharapkan dapat menjawab apa yang tersirat dari hasil-hasil analisa dan pengumpulan data.

\section{Konstruksi (Contruction)}

Kegiatan ini menggabungkan pembentukan kode-kode (kode generation) 
bisa secara manual maupun otomatis dan pengujian yang sangat dibutuhkan untuk menemukan kekeliruan-kekeliruan/kesalahankesalahan dalam kode program komputer yang dihasilkan sebelumnya.

5. Penerapan (Deployment)

Perangkat lunak disajikan kepada pelanggan yang kemudian mengevaluasi produk yang disajiakan dan akan memberikan umpan balik berdasarkan evaluasi tersebut.

\subsection{Perangkat lunak}

Perangkat lunak adalah perintah program komputer yang bila dieksekusi memberikan fungsi dan unjuk kerja seperti yang diinginkan. Struktur data yang memungkinkan program memanifulasi informasi secara profesional dan dokumen yang mengambarkan operasi dan kegunaan program. (Rossa, 2015).

\subsection{Administrasi Kependudukan}

Administrasi Kependudukan adalah rangkaian kegiatan penataan dan penertiban dalam penertiban dokumen dan Data Kependudukan melalui Pendaftaran Penduduk, Pencatatan Sipil, pengelolaan informasi Administrasi Kependudukan serta pendayagunaan hasilnya untuk pelayanan publik dan pembangunan sector lain. Penduduk adalah Warga Negara Indonesia dan Orang Asing yang bertempat tinggal di Indonesia. Sedangkan pengertian Kependudukan itu sendiri adalah hal yang berkaitan dengan jumlah, ciri utama, pertumbuhan, persebaran, mobilitas, penyebaran, kualitas, kondisi, kesejahteraan yang menyangkut politik, ekonomi, sosial, budaya, agama, serta lingkungan penduduk tersebut. (Lestari, 2014)

\subsection{Penduduk}

Dalam sosiologi penduduk adalah kumpulan manusia yang menempati wilayah geografi dan ruang tertentu. (Kusumawati, 2014).

\subsection{Struktur Tabel}

\subsubsection{Tabel Lahir}

Berikut ini adalah rancangan tabel database yang digunakan untuk pendataan data penduduk yang baru lahir, atau pertambahan penduduk baru di suatu desa.

Tabel 1. Lahir

\begin{tabular}{llll}
\hline No & Field Name & \multicolumn{1}{c}{ Type } & \multicolumn{1}{c}{ Size } \\
\hline 1 & Id_Lahir* & Int & 10 \\
\hline 2 & Nama & Varchar & 20 \\
\hline 3 & JK & Varchar & 2 \\
\hline 4 & Tem_Lahir & Varchar & 20 \\
\hline 5 & Tgl_Lahir & Date & - \\
\hline 6 & Nama_Ayah & Varchar & 20 \\
\hline 7 & Nama_Ibu & Varchar & 20 \\
\hline 8 & Desa & Varchar & 15 \\
\hline 9 & Kecamatan & Varchar & 10 \\
\hline 10 & Kabupaten & Varchar & 10 \\
\hline 11 & Provinsi & Varchar & 15 \\
\hline
\end{tabular}

*) Primary key

\subsubsection{Tabel KTP}

Berikut ini adalah rancangan tabel database yang digunakan untuk mencatat data penting yang merupakan identitas para penduduk disuatu desa Berdasarkan KTP.

Tabel 2. Kartu Tanda Penduduk (KTP)

\begin{tabular}{llll}
\hline No & Field Name & Type & Size \\
\hline 1 & NIK* & Int & 10 \\
\hline 2 & Nm_Lengkap & Varchar & 20 \\
\hline 3 & JK & Varchar & 2 \\
\hline 4 & Tem_Lahir & Varchar & 20 \\
\hline 5 & Tgl_Lahir & Date & - \\
\hline 6 & Desa & Varchar & 15 \\
\hline 7 & Kecamatan & Varchar & 10 \\
\hline 8 & Kabupaten & Varchar & 10 \\
\hline
\end{tabular}




\begin{tabular}{llll}
\hline 9 & Provinsi & Varchar & 15 \\
\hline 10 & Gol_Darah & Varchar & 2 \\
\hline 11 & Agama & Varchar & 10 \\
\hline 12 & Pekerjaan & Varchar & 10 \\
\hline 13 & Pend_Terakhir & Varchar & 3 \\
\hline 14 & Status_Perkawinan & Varchar & 10 \\
\hline 15 & Kewarganegaraan & Varchar & 3 \\
\hline 16 & Masa Berlaku & Date & -
\end{tabular}

*) Primary key

\subsubsection{Tabel KK}

Berikut ini adalah rancangan tabel database yang digunakan untuk mencatat data penting yang merupakan identitas para penduduk disuatu desa Berdasarkan KK.

Tabel 3. Kartu Keluarga (KK)

\begin{tabular}{lllc}
\hline No & \multicolumn{1}{c}{ Field Name } & Type & Size \\
\hline 1 & No_KK* & Int & 15 \\
\hline 2 & Nm_kpl Keluarga & Varchar & 20 \\
\hline 3 & JK & Varchar & 2 \\
\hline 4 & Tem_Lahir & Varchar & 20 \\
\hline 5 & Tgl_Lahir & Date & - \\
\hline 6 & Desa & Varchar & 15 \\
\hline 7 & Kecamatan & Varchar & 10 \\
\hline 8 & Kabupaten & Varchar & 10 \\
\hline 9 & Provinsi & Varchar & 15 \\
\hline 10 & Agama & Varchar & 10 \\
\hline 11 & Pekerjaan & Varchar & 10 \\
\hline 12 & Pend_Terakhir & Varchar & 3 \\
\hline 13 & Status_Perkawinan & Varchar & 15 \\
\hline 14 & Status_keluarga & Varchar & 6 \\
\hline 15 & Kewarganegaraan & Varchar & 3 \\
\hline
\end{tabular}

*) Primary key

\subsection{Desain Form}

\subsubsection{Desain Form Halaman Utama}

Tampilan halaman utama berisi pilihan menu-menu yang dapat diakses oleh user untuk melihat informasi data penduduk yang telah dimasukan admin, seperti pada gambar dibawah ini :

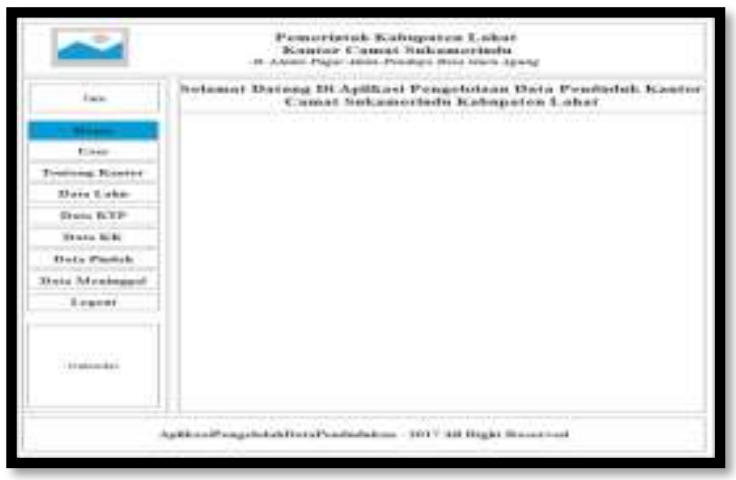

Gambar 2. Desain Form Halaman Utama

\subsubsection{Desain Form Halaman Login}

Tampilan menu login berupa nama dan password untuk masuk ke dalam sistem atau untuk membuka program pertama kali, seperti pada gambar dibawah ini :

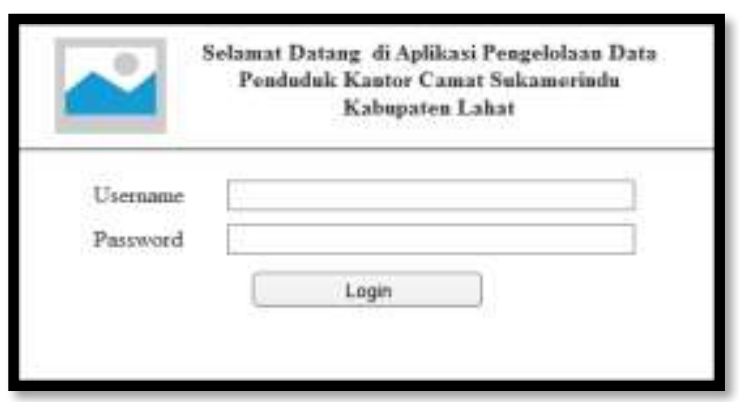

Gambar .3 Desain Form input Login

\subsubsection{Desain Form Halaman Admin}

Tampilan halaman admin berisi pilihan menu-menu yang dapat diakses oleh admin untuk menambah, mengubah dan menghapus data yang di dalam sistem, seperti pada gambar dibawah ini :

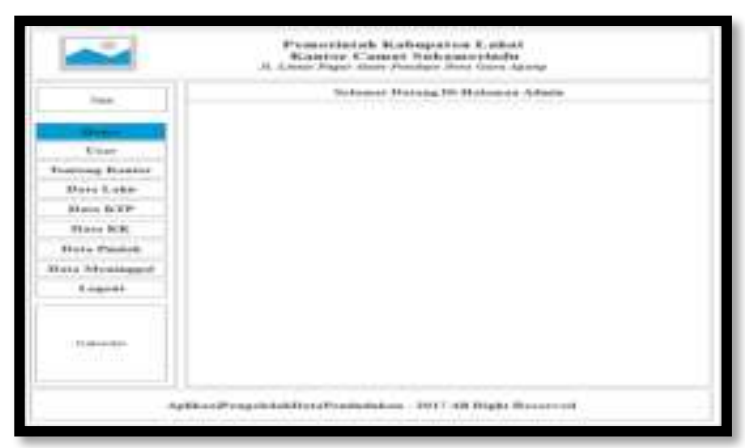

Gambar 4. Desain Form Halaman Admin 


\subsubsection{Desain Form Halaman Camat}

Tampilan halaman camat berisi pilihan menu-menu yang dapat diakses oleh camat untuk melihat laporan data penduduk yang telah dibuat oleh admin, seperti pada gambar dibawah ini :

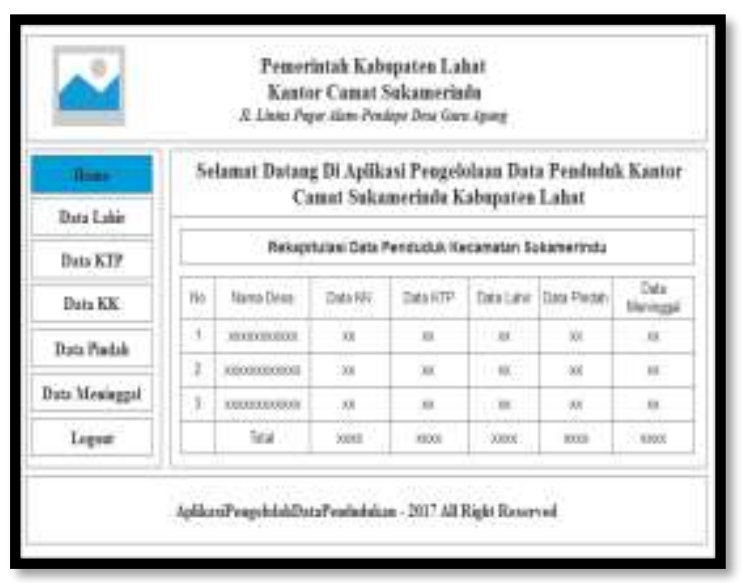

Gambar 5. Desain Form Halaman Camat

\subsubsection{Desain Form Input Data Lahir}

Tampilan ini berisi tampilan untuk penambahan data penduduk berdasarkan data kelahiran penduduk, seperti pada gambar dibawah ini :

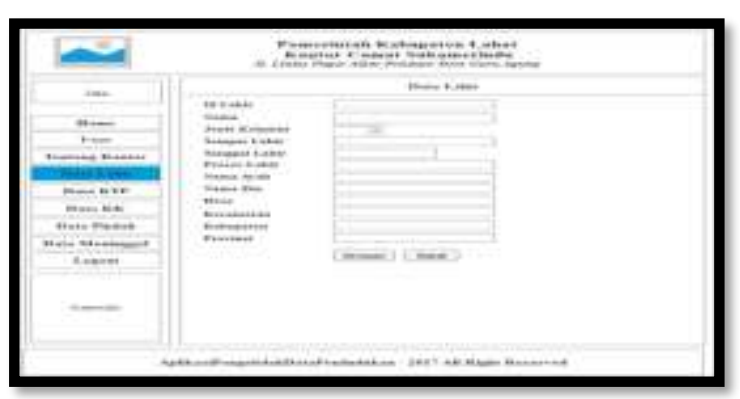

Gambar 6. Desain Form Input Data Lahir

\subsubsection{Desain Form Input Data KTP}

Tampilan ini berisi tampilan untuk penambahan data penduduk berdasarkan data Kartu Tanda Penduduk, seperti pada gambar dibawah ini :

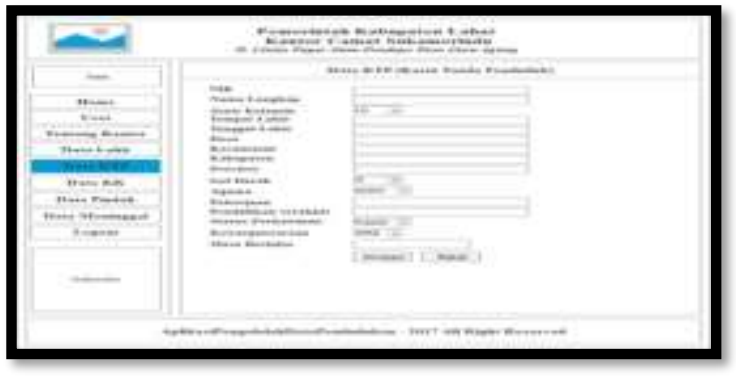

Gambar 7. Desain Form Input Data KTP

\subsubsection{Desain Form Input Data KK}

Tampilan ini berisi tampilan untuk penambahan data penduduk berdasarkan data Kartu Keluarga(KK), seperti pada gambar dibawahini:

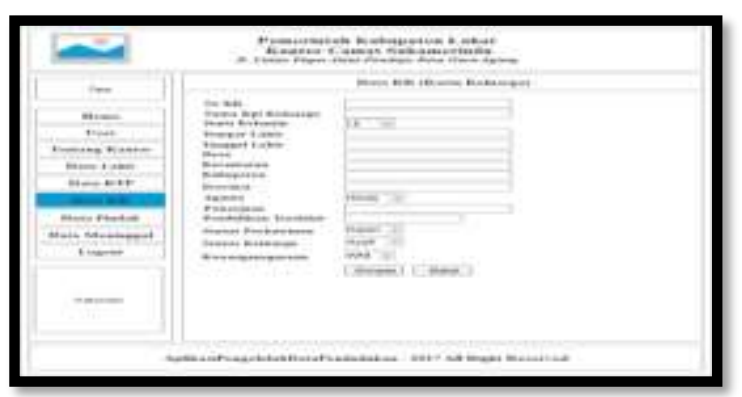

Gambar 8. Desain Form Input Data KK

\section{HASIL DAN PEMBAHSAN}

Hasil yang diperoleh dari penelitian ini berupa Aplikasi Pengelolaan Data Penduduk Pada Kantor Camat Sukamerindu. Adanya perangkat lunak bantu pengelolaan data penduduk ini dapat membantu pekerjaan petugas dalam mengisi dan mencari data penduduk kecamatan sukamerindu.

\subsection{Halaman Utama}

Halaman utama merupakan halaman awal yang ditampilkan pada saat aplikasi dijalankan baik admin, camat maupun user membuka aplikasi pengelolaan data penduduk pada kantor kecamatan sukamerindu. halaman ini memuat ucapan selamat datang di aplikasi 
pengelolaan data penduduk pada kantor camat sukamerindu. Dimana tampilan yang muncul pertama kali adalah halaman utama sistem pengelolaan data penduduk kantor camat sukamerindu. dapat dilihat pada gambar berikut ini.

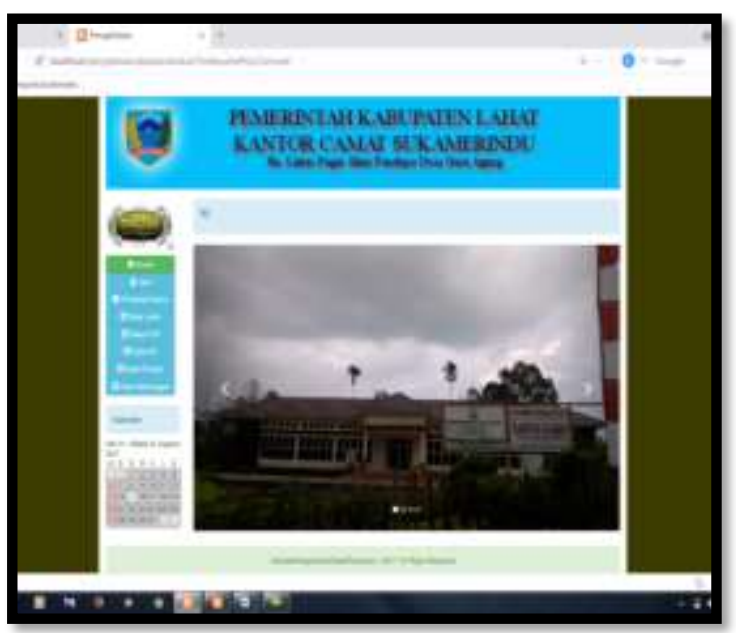

Gambar 9. Halaman Utama

\subsection{Halaman Login}

Halaman ini menampilkan menu inputan yang berupa username dan password sebagai syarat untuk dapat masuk kedalam sistem, baik itu seorang admin maupun seorang camat. Dimana tampilannya seperti gambar dibawah ini.

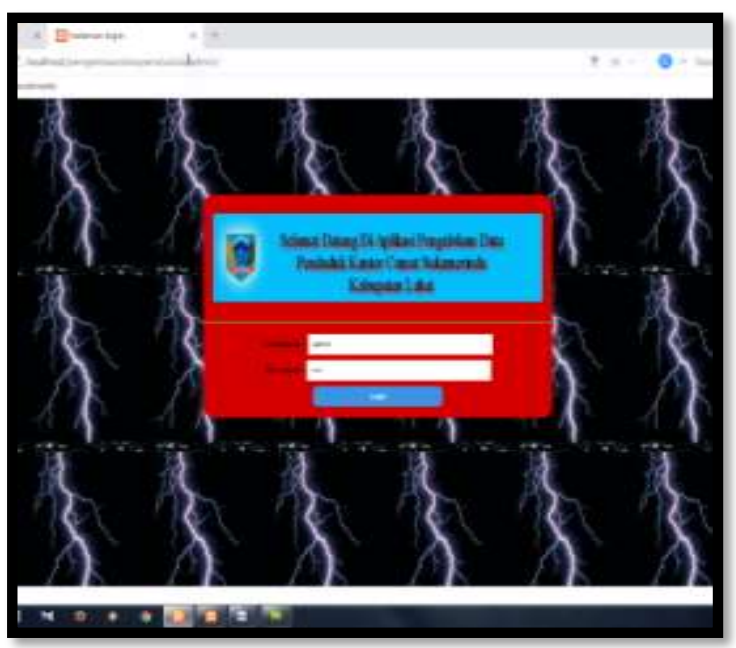

Gambar 10. Halaman Login

\subsection{Halaman Admin}

Halaman ini menampilkan menu-menu pilihan yang dapat diakses oleh admin, dimana admin dapat melakukan proses menambah, mengubah dan menghapus data. Berikut menu yang terdapat di halaman admin.

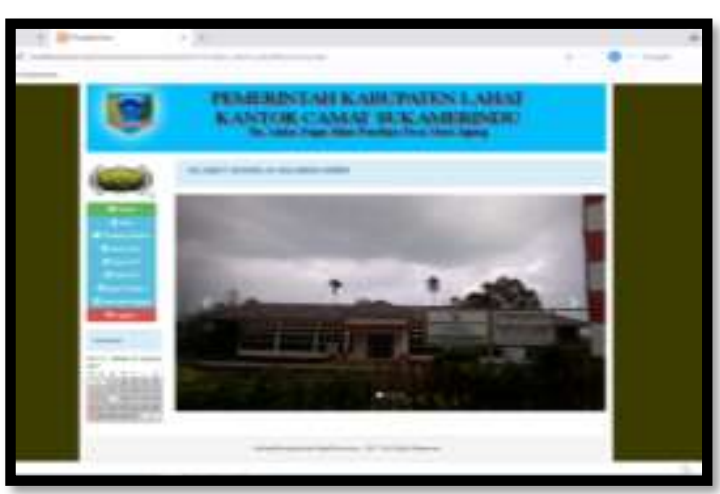

Gambar 11. Halaman Admin

\subsection{Halaman Camat}

Halaman ini menampilkan menu-menu pilihan yang dapat diakses oleh camat sebagai laporan dari admin. Dimana memiliki menumenu seperti gambar dibawah ini.

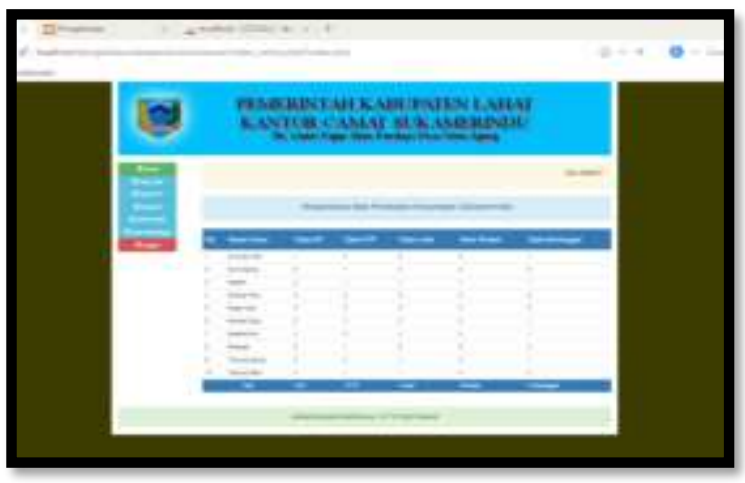

Gambar 12. Halaman Camat

\subsection{Halaman Input Data Lahir}

Halaman ini menampilkan formulir yang bisa diisi untuk menambah data berdasarkan penduduk yang baru lahir, namun pengisian formulir tersebut hanya bisa dilakukan oleh admin. 


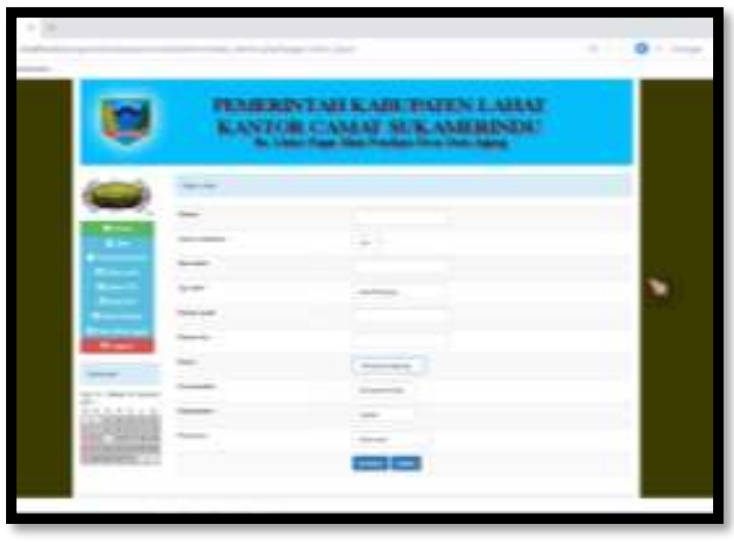

Gambar 13. Form Input Data Lahir

\subsection{Halaman Input Data KTP}

Halaman ini menampilkan formulir yang bisa diisi untuk menambah data berdasarkan data KTP (Kartu Tanda Penduduk) yang telah dimiliki penduduk, namun pengisian formulir tersebut hanya bisa dilakukan oleh admin.

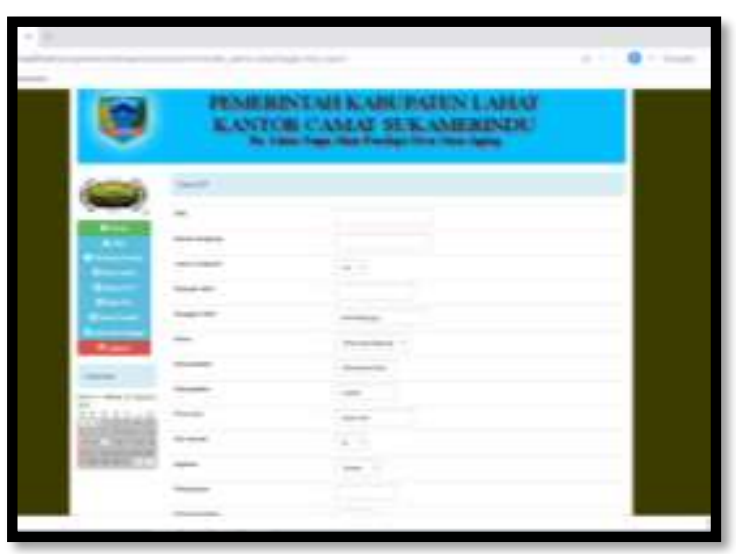

Gambar 14. Form Input Data KTP

\subsection{Halaman Input Data KK}

Halaman ini menampilkan formulir yang bisa diisi untuk menambah data berdasarkan data KK (Kartu Keluarga) yang dimiliki peduduk, namun pengisian formulir tersebut hanya bisa dilakukan oleh admin .

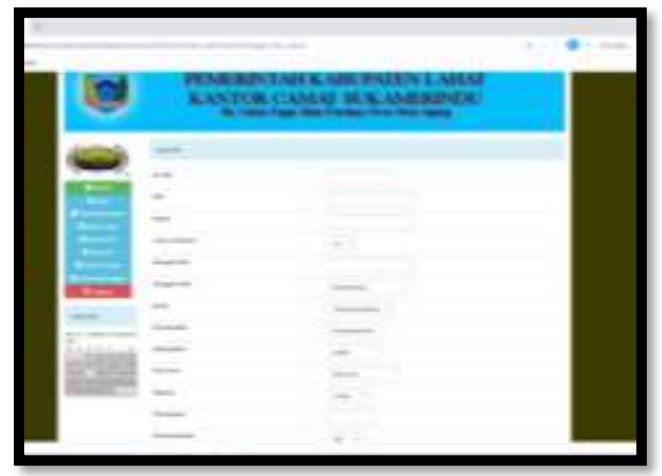

Gambar 15. Form Input Data KK

\subsection{Halaman Input Data Pindah}

Halaman ini menampilkan formulir yang bisa diisi untuk menambah data berdasarkan penduduk yang pindah desa, namun pengisian formulir tersebut hanya bisa dilakukan oleh admin.

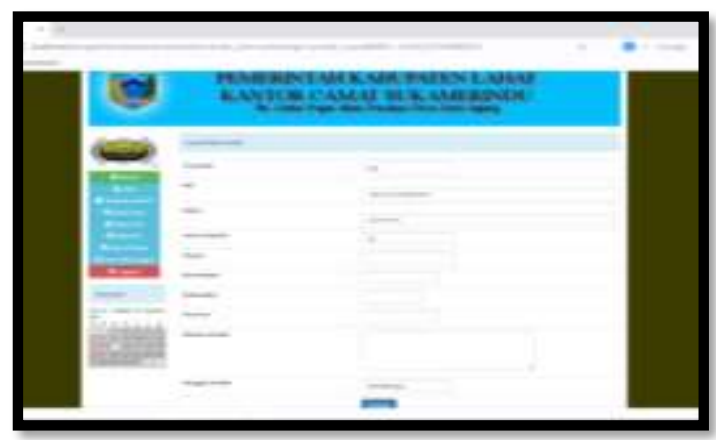

Gambar 16. Form Input Data Pindah

\subsection{Halaman Input Data Meniggal}

Halaman ini menampilkan formulir yang bisa diisi untuk menambah data berdasarkan penduduk yang meninggal dunia, namun pengisian formulir tersebut hanya bisa dilakukan oleh admin 


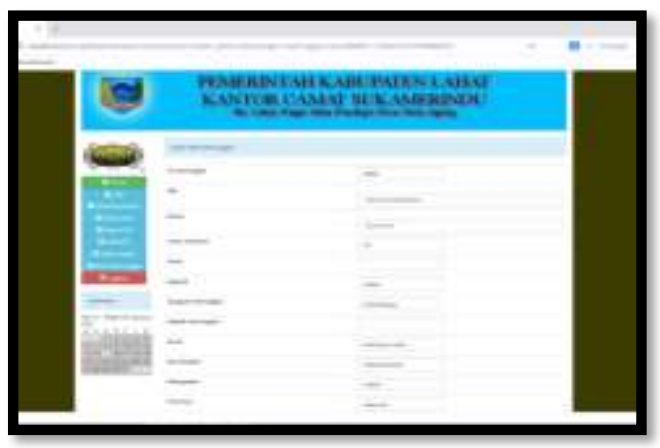

Gambar 17. Form Input Data Meninggal

\subsection{Halaman Output Data Lahir}

Halaman ini menampilkan hasil dari input yang dilakukan oleh admin. Sehingga menghasilkan output yang akan menjadi informasi untuk user. Berikut gambar yang di tampilkan.

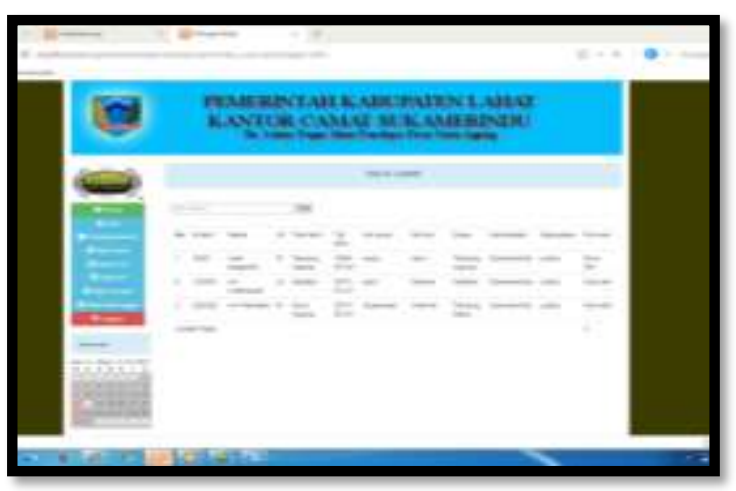

Gambar 18. Output Data Lahir

\subsection{Halaman Output Data KTP}

Halaman ini menampilkan hasil dari input yang dilakukan oleh admin. Sehingga menghasilkan output yang akan menjadi informasi untuk user. Berikut gambar yang di tampilkan.

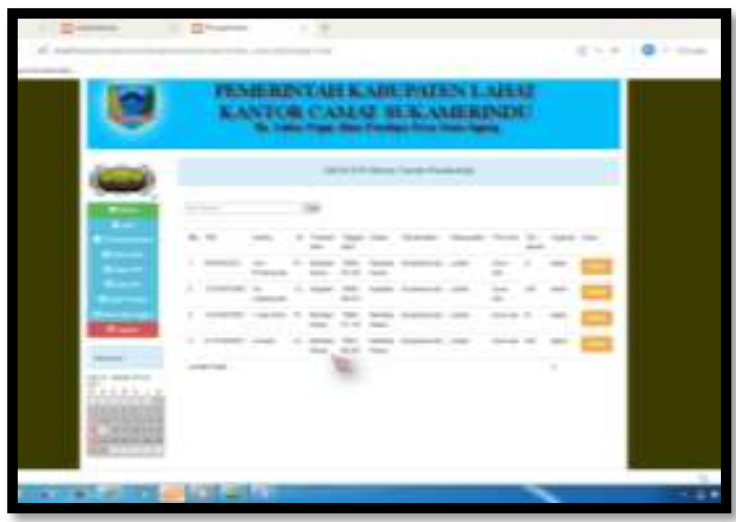

Gambar 19.Output Data KTP

\subsection{Halaman Output Data KK}

Halaman ini menampilkan hasil dari input yang dilakukan oleh admin. Sehingga menghasilkan output yang akan menjadi informasi untuk user. Berikut gambar yang di tampilkan.

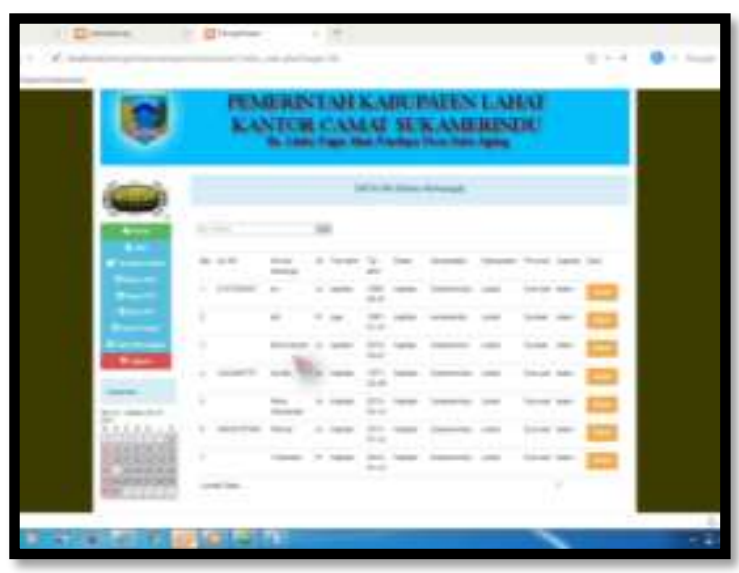

Gambar 20. Output Data KK

\section{SIMPULAN}

Kesimpulan dari penelitian ini adalah Aplikasi pengelolaan Data Penduduk Pada Kantor Camat Sukamerindu dapat dibuat dengan menggunakan pemrograman $P H P$ dan database MySql. dan mempermudah petugas dalam mengelola data penduduk kecamatan sukamerindu. 


\section{DAFTAR RUJUKAN}

Alfatah, H. (2007). Analisis \& Perancangan Sistem Informasi. Yogyakarta: Andi.

Andi. (2008). Adobe Dreamweaver CS3 \& PHP. Madiun.

Andi. (2016). Pemrograman PHP dan MySQL.

Kusumawati, T. T. (2014). Sistem Informasi Pendataan Penduduk Dilengkapi Dengan Sms Gateway Sebagai Media Penyampaian Informasi Pada Kantor Kelurahan Desa Kotesan. AMIKOM Yogyakarta.

Lestari, S. (2014). Analisis Dan Perancangan Sistem Informasi Pengolahan Data Penduduk Di Kantor Kecamatan Sungaiselan Bangka Tengah. Stmik Atma Luhur Pangkalpinang.

Merzalino. (2013). Aplikasi Penolahan Data Kependudukan Di Kecamatan Lawang Kidul Tanjung Enim Menggunakan Borland Delphi 2007 dan SQL Server 2008. POLITEKNIK PalComTech Palembang.

Muttaqien. (2014). ANALISIS DAN PERANCANGAN SISTEM INFORMASI Kependudukan Pada Pemerintah Desa Bangunjiwo Berbasis WEB. STMIK AMIKOM Yogyakarta.

Puspita, D. (2017). Perangkat Lunak Bantu Pengelolaan Surat Pada Dinas Perindagkop, UKM dan Pengelolaan Pasar Kota Pagar Alam. Jurnal

Rohmat Taufiq, S. M. (2013). Sistem Informasi Manajemen.

Rohmat Taufiq, S. M. (2013). Sistem Informasi Manajemen. Yogyakarta.

Rosa. (2015). Rekayasa Perangkat Lunak Tertruktur \& Berorientasi Objek. Bandung: Informatika Bandung.

Rossa. (2015). Rekayasa Perangkat Lunak terstruktur \& berorientasi objek. Bandung: Informatika Bandung.
Taufik, R. (2013). Sistem informasi Manajemen . Tanggerang: Graha Ilmu.

Taufiq, R. (2013). Sistem Informasi Manajemen. Tanggerang: Graha Ilmu. 
Desi Puspita, Buhori Muslim, Siti Aminah 